\title{
Legionellosis- A Mini Review
}

\author{
Arnav Wadhawan ${ }^{1}$ and Rajinder PS Bajwa ${ }^{2 *}$ \\ ${ }^{1}$ Ridley College, Canada \\ ${ }^{2}$ Niagara Falls Memorial Medical Center, USA
}

Submission: August 10, 2017; Published: August 22, 2018

*Corresponding author: Rajinder PS Bajwa, Niagara Falls Memorial Medical Center, Niagara Falls, NY, USA, Email: Rajinder.bajwa@nfmmc.org

\section{Mini Review}

Legionellosis is the term used to describe clinical manifestations of infection caused by the Legionella bacteria. It includes Legionnaires disease (LD), focal non-pulmonary infections and Pontiac fever. LD is a type of bacterial pneumonia, while Pontiac fever is a several days long non-pneumonic, febrile, influenza like illness associated with exposure to Legionella spp. That resolves spontaneously.

Legionnaires disease was first described during an outbreak at a convention of the American legion in Philadelphia in 1976 [1]. Twenty-nine of 182 cases were fatal. Extensive epidemiologic work led to identification of the bacterium.

The legionella spp. is small gram-negative rods with fastidious growth requirements. More than 58 different Legionella spp. have been described, about half of which have been reported to infect humans [2]. Legionella pneumophila (Lp) is the most commonly encountered species. Lp contains at least 16 different serogroups. Lp serogroup 1 is the most common clinical isolate. The most common non Lp species isolated from humans are L.longbeachae, L.micdadei, L.bozemanae, and L.dumoffii [3]. These constitute less than $5 \%$ of culture -proven cases in North America. This bacteria needs special growth medium which contains Iron, L-cysteine, $\alpha$-ketoglutarate, and charcoal-containing yeast extract agar buffered with an organic buffer (BCYE $\alpha$ agar).

Legionella bacteria are found in natural aqueous environment, in lakes, streams and costal oceans. Warm water $\left(25^{\circ} \mathrm{C}-40^{\circ} \mathrm{C}\right)$ supports its growth [4]. Free living amoebas in the same waters support the intracellular growth and survival of Legionella. Almost all cases of LD results from this bacteria growing in water heaters, warm water baths, warm water plumbing systems and air conditioning and other types of cooling towers. Rain puddles in tropical regions, tsunami related water exposure, and windshield viper fluid are few other reported sources of infection. One exception to water as risk factor is that Llb, which is mainly transmitted through soil contact, especially from potting soil.

LD is initiated by inhalation of aerosolized Legionella bacteria. After bacteria enter lung they are phagocytosed by alveolar macrophages. Bacteria prevents fusion of phagosome to lysosomes or endosomes, thus avoiding acidification and degradative enzymes. After sufficient intracellular replication, the bacteria kill the macrophage and then rephagocytosed by other macrophage. This process recruits other inflammatory cells leading to pneumonia [5].

Pathogenesis of Pontiac fever is not known with certainty. It is believed that PF is caused by inhalation of disease causing environmental aerosol derived from water containing microorganisms including Legionella bacteria.

The incubation period of LD is between 2-10 days and for PF 4 hours- 3 days [1]. Person-to-person transmission of either LD or Pontiac fever does not occur. Legionella spp. is ubiquitous in environment. However, disease is not that common. Legionella is causative organism of only $0.5-10 \%$ hospitalized cases of community acquired pneumonia, an average value is probably $2 \%$ even in the geographic regions with excellent diagnostic capabilities [6]. Male gender, cigarette smoking, chronic heart or lung disease, diabetes, end stage renal failure, organ transplantation, immunosuppression, some forms of cancer and old age are well known host risk factors. Also important are environmental and bacterial factors such as relative bacterial virulence, bacterial aerosol stability, organism growth conditions and factors that facilitate the spread of bacterium from contaminated water to host, such as wind direction, relative humidity and aerosol formation.

LD is one of cause of bacterial pneumonia. Sometimes it is characterized by fever with pulse-temperature dissociation, myalgia, few pulmonary symptoms, nonproductive cough, diarrhea, confusion, hyponatremia, hypophosphatemia, and elevated liver enzymes. This symptom complex, however, is neither specific nor frequent enough to allow differentiation of LD from other common causes of community acquired pneumonia [7]. LD starts with prodrome of headache, muscle aches, and anorexia. Fever accompanies these symptoms. Cough may develop hours to days after onset of prodrome. Careful examination always demonstrates findings of pneumonia including focal rales and patchy infiltrate to dense focal consolidation on Chest $\mathrm{X}$ ray. 
Diagnosis of LD requires high degree of suspicion and keen consideration of epidemiology. Various laboratory tests can be sued including sputum culture, urine antigen testing, immunofluorescent microscopy, paired serum antibody and molecular amplification techniques. Culture requires special media; hence laboratory needs to be informed about this. Yield of sputum culture varies between 20\%-95\%. Many clinical laboratories have neither expertise nor ability to properly perform these specialized cultures. Urine antigen testing has revolutionized the diagnosis. It is easy to perform and has fast turnaround time. The average sensitivity of this test is in the range of $70 \%$ to $80 \%$ [8]. Big caveat in using urine antigen is that it detects Lp serogroup 1 and poorly sensitive for other Lp serogroups. Hence negative test should be taken with grain of salt. Urine antigen test can be positive for months after the initial infection.

Legionella bacteria are intracellular, this means antimicrobials which are concentrated intracellularly are going to be more efficacious. The macrolides, quinolones, and tetracyclines all meet these criteria. Prospective, adequately sized clinical trials of antimicrobial therapy for LD have not been performed. In absence of these, decisions about antimicrobials must be made on the basis of experimental animal and cell culture studies [9]. For mild pneumonia in immunocompetent host first choice antibiotics include: Azithromycin 500mg daily for 3-5 days, Levofloxacin 500mg daily for 7-10 days, ciprofloxacin 500 twice a day for 7-10 days, moxifloxacin 400mg daily for 7-10 days or clarithromycin 500mg twice a day for 1014 days. Second choice for these patients will be Doxycycline $200 \mathrm{mg}$ loading dose followed by $100 \mathrm{mg}$ twice a day for 10-14 days or Erythromycin 500mg four times a day for 10-14 days $[9,10]$.

In severe cases or immunocompromised host treatment of LD includes using Azithromycin 500mg daily for 5-7 days or levofloxacin $500 \mathrm{mg}$ daily for $7-10$ days or $750 \mathrm{mg}$ daily for 5-7 days. Second lie drugs for these severe cases include Ciprofloxacin $750 \mathrm{mg}$ twice daily for 14 days or moxifloxacin $400 \mathrm{mg}$ daily for 14 days or Erythromycin 750-1000mg IV four times a day for 3-7 days followed by $500 \mathrm{mg}$ four times a day for total of 21 days or Clarithromycin 500mg IV twice a day for 3-7 days followed by $500 \mathrm{mg}$ twice a day for total of 21 days.

Failure to respond to specific therapy for LD should bring into question the validity of the diagnosis, the possibility of coinfection or superinfection.

No human vaccine exists for $\mathrm{LD}$, and prior infection does not prevent reinfection [11]. Antibiotic prophylaxis prevents LD and should be considered during nosocomial epidemics and for high-risk population before control of an epidemic. Engineering modifications and maintenance of water supply systems is important to prevent contamination of water with Legionella. Disinfection of water distribution systems and surveillance for Legionella contamination should be a routine practice to prevent disease transmission from contaminated water.

\section{References}

1. Fraser DW, Tsai TR, Orenstein W, Parkin WE, Beecham HJ, et al. (1977) Legionnaires' disease: description of an epidemic of pneumonia. $\mathrm{N}$ Engl J Med 297(22): 1189-1197.

2. Garrity GM, Bell JA, Lilburn T (2005) Order VI: Legionellales ord.nov. In: Brenner DJ Krieg NR Staley JT Garrity GM (Eds.), Bergey's Manual of Systematic Bacteriology. ( $2^{\text {nd }}$ edn), Springer, New York, NY, USA, pp. 210-247.

3. Yu VL, Plouffe JF, Pastoris MC, Stout JE, Schousboe M, et al. (2002) Distribution of Legionella species and serogroups isolated by culture in patients with sporadic community-acquired legionellosis: an international collaborative survey. J Infect Dis 186(1): 127-128.

4. Fields BS, Benson RF, Besser RE (2002) Legionella and Legionnaires' disease: 25 years of investigation. Clin Microbiol Rev 15(3): 506-526.

5. Winn WC Jr, Myerowitz RL (1981) The pathology of the Legionella pneumonias. A review of 74 cases and the literature. Hum Pathol 12(5): 401-422.

6. Breiman RF, Butler JC (1998) Legionnaires' disease: clinical, epidemiological, and public health perspectives. Semin Respir Infect 13(2): 84-89.

7. Kirby BD, Snyder KM, Meyer RD, Finegold SM (1980) Legionnaires' disease: report of sixty-five nosocomially acquired cases of review of the literature. Medicine (Baltimore) 59(3): 188-205.

8. Helbig JH, Uldum SA, Bernander S, Lück PC, Wewalka G, et al. (2003) Clinical utility of urinary antigen detection for diagnosis of communityacquired, travel-associated, and nosocomial legionnaires' disease. J Clin Microbiol 41(2): 838-840.

9. Edelstein PH (1995) Antimicrobial chemotherapy for legionnaires' disease: a review. Clin Infect Dis 21 Suppl 3: S265-S276.

10. Griffin AT, Peyrani P, Wiemken T, Arnold F (2010) Macrolides versus quinolones in Legionella pneumonia: results from the CommunityAcquired Pneumonia Organization international study. Int J Tuberc Lung Dis 14(4): 495-499.

11. Meyer RD, Edelstein PH, Kirby BD, Louie MH, Mulligan ME, et al. (1980) Legionnaires' disease: unusual clinical and laboratory features. Ann Intern Med 93(2): 240-243. 
This work is licensed under Creative Commons Attribution 4.0 License DOI: 10.19080/JOJCS.2018.08.555732

\section{Your next submission with Juniper Publishers} will reach you the below assets

- Quality Editorial service

- Swift Peer Review

- Reprints availability

- E-prints Service

- Manuscript Podcast for convenient understanding

- Global attainment for your research

- Manuscript accessibility in different formats

( Pdf, E-pub, Full Text, Audio)

- Unceasing customer service

Track the below URL for one-step submission https://juniperpublishers.com/online-submission.php 